\title{
Sustainability and the UK Waste Management Industry
}

\author{
Peter Jones ${ }^{1 *}$, Daphne Comfort ${ }^{1}$
}

${ }^{1}$ University of Gloucestershire, U.K.

*Corresponding Author: pjones@glos.ac.uk

Citation: Jones, P. and Comfort, D. (2018). Sustainability and the UK Waste Management Industry. European Journal of Sustainable Development Research, 2(1), 02. https://doi.org/10.20897/ejosdr/79227

Published: January 30, 2018

\begin{abstract}
The aim of this paper is to offer an exploratory review of the approaches to sustainability within the UK's waste management industry. The paper begins with brief outlines of the waste management industry in the UK and the growing interest in corporate sustainability. This is followed by a review of the most recent sustainability reports published by the leading waste management companies operating within the UK and the paper concludes by offering some reflections on current approaches to sustainability within the industry. More critically the authors suggest that the selected companies' commitments to sustainability are couched within existing business models centred on continuing growth and consumption and that current policies might be viewed as little more than genuflections to sustainability. The paper provides an accessible commentary on current approaches to sustainability in the waste management industry within the UK and as such it will interest professionals working in the industry as well as academics and students interested in management and business studies, resource management and sustainability.
\end{abstract}

Keywords: waste management industry, corporate sustainability, sustainability reporting, circular economy, economic growth

\section{INTRODUCTION}

Sustainability has become an increasingly important priority for the waste management industry within the UK. Alan Whitehead, Co-Chair of the Associate Parliamentary Sustainable Resources Group, for example, claimed that the time when the waste industry was just about that -waste - is long gone. Now it is all about sustainable resources and developing the necessary means to capture and put to good use as much as possible of the waste stream' (Associate Parliamentary Sustainable Resource Group 2012, p. 16). The 'key aim' of the 'The Waste Management Plan for England' (Department for Environment, Food and Rural Affairs 2013.p.1), is to set out our work towards a zero waste economy as part of the transition to a sustainable economy.' Under the banner 'Delivering Sustainable Growth' the Environmental Services Association (2016, p. 1) has looked to demonstrate how the UK's waste management industry 'benefits, people, the environment and the economy.'

However the concept of sustainability is contested and 'means different things to different people' (Aras and Crowther 2008, p.436). On the one hand there are definitions essentially based in and around ecological principles and secondly there are definitions which look to embrace social and economic development as well as environmental goals, and which also look to embrace equity in meeting human needs. More critically Hudson (2005, p. 241) argued that definitions range from 'pallid blue green to dark deep green.'The former Hudson (2005, p. 241) suggested centre on 'technological fixes within current relations of production, essentially trading off economic against environmental objectives, with the market as the prime resource allocation mechanism' while for the latter 'prioritizing the preservation of nature is preeminent.' In a similar vein a distinction is often made between 'weak' and 'strong' sustainability and Roper (2012, 
p.72) suggested that 'weak sustainability prioritizes economic development, while strong sustainability subordinates economies to the natural environment and society, acknowledging ecological limits to growth.'

At the same time it is important to recognise that a number of critics see the growing business interest in sustainability as little more than a thinly veiled and cynical ploy, popularly described as 'green wash', designed to attract socially and environmentally conscious consumers while sweeping pressing environmental and social concerns under the carpet. So seen, corporate commitments to sustainability might be characterised by what Hamilton (2009, p. 573-574) described as 'shifting consciousness' towards 'what is best described as green consumerism.'This he sees as 'an approach that threatens to entrench the very attitudes and behaviours that are antithetical to sustainability' and argues that 'green consumerism has failed to induce significant inroads into the unsustainable nature of consumption and production.' Further, some critics (e.g. Hamilton, 2009), and recent issues, for example in the motor vehicle industry, would suggest that corporate approaches to sustainability and sustainability reporting amount to little more than so called greenwash, which effectively provides opportunities for companies to promote their environmental credentials whist pursuing profit maximisation goals. Perhaps more radically Kahn (2010, p. 43) argued that 'green consumerism' is 'an opportunity for corporations to turn the very crisis that they generate through their accumulation of capital via the exploitation of nature into myriad streams of emergent profit and investment revenue.'

With these thoughts in mind, the aim of this paper is to offer an exploratory review of the approaches to sustainability within the UK's waste management industry. The waste management industry is essentially a service industry. While research has been undertaken on approaches to sustainability in a number of elements within the service sector, for example, on retailing (Weise et al., 2012) and the hospitality industry (Jones et al. 2016), similar work on the waste management industry is more limited though some work has been published on waste management in the construction industry (Ortiz-Rodriguez et al., 2009). The paper begins with brief outlines of the waste management industry and the growing interest in sustainability reporting. This is followed by a review of the most recent sustainability reports and published by the leading waste management companies operating within the UK and the paper concludes by offering some reflections on current approaches to sustainability within the industry.

\section{WASTE MANAGEMENT IN THE UK}

The UK generates over 200 million tonnes of waste each year and this waste includes large volumes of mineral waste, soils, dredging spoils and households waste as well as smaller volumes of metallic, plastic, paper and packaging, glass and wood wastes. Households account for some $14 \%$ of the total waste generated, the construction demolition and excavation sector accounts for some $60 \%$, commercial and industrial sources for some $14 \%$ with other sources accounting for the remainder (GOV.UK 2016). Within the UK, waste management includes a number of elements including the collection of both municipal and commercial and industrial waste, various forms of treatment of these wastes, recycling, generation of energy from waste and waste disposal. In 2014 some $44 \%$ of all waste generated in the UK was recycled and $23 \%$ sent to land fill sites while the corresponding figures for energy recovery, incineration, backfilling and land treatment and release into water bodies were 1\%, $4 \%, 10 \%$ and $18 \%$ respectively (Department for Environment, Food and Rural Affairs 2017). Traditionally, landfill, the deposit of waste onto or into land, was the most common method of waste management within the UK. However the introduction of a number of European Union and UK Government directives have seen an increasing decline in this method of waste management. The European Union Waste Framework Directive, for example, introduced in 2008, set out five steps (the so called 'waste hierarchy') for dealing with waste, ranked according to environmental impact, around waste prevention, preparation for reuse, recycling, energy generation identified landfill as the last resort. This Directive, along with UK programmes of privatisation, contracting out and deregulation introduced from the 1970's onwards, have created new landscape for the waste management industry and have encouraged the emergence and growth of what is new waste management market.

The waste management industry in the UK, which covers the collection, treatment and disposal of waste has an annual turnover of some $f^{9}$ billion, with a Gross Added Value of $f^{6} 6.4$ billion and embraces some 3,000 companies employing 70,000 people (Gov.UK 2014). The waste collection sector of the waste management sector is fragmented, particularly in the commercial and industrial sector, but the treatment, recycling and recovery sector is much more concentrated, so much so that Apex Insight (2013) estimated that the top five companies accounted for $45 \%$ of the market. That said the leading players within the waste management industry exhibit considerable diversity. Three of the top five companies within the industry, namely Veolia Environmental Services, Suez Environment and FCC Environmental are in foreign ownership. Veolia Environmental Services, the leading player in the UK, for example, is a French multinational company with operations in 48 countries and its activities include water distribution, energy supply and construction as well as waste management.

By way of contrast Biffa group, the second largest player, is a privately owned British company founded in 1912. The company's operations now cover virtually all the UK, it provides collection, recycling, treatment, 
disposal and energy generation services, collects domestic waste from 2.4 million households and has 75,000 business customer and 7,000 employees. The Pennon Group, a British based company, focuses on water supply, waste water treatment and energy regeneration and waste management and its activities are concentrated in the South and North West of England and in Central Scotland. SRCL describes itself as 'the UK's leading health care waste specialist' while DCC describes itself as 'an international sales, marketing, distribution and business services support group' and its four divisions focus on the sales, marketing and distribution of oil and gas; the provision of healthcare products and services; the sales, marketing and distribution of technology products; and the provision of a range of waste management and recycling services.

\section{CORPORATE SUSTAINABILITY AND SUSTAINABILITY REPORTING}

The concept of sustainability is not new. Du Pisani (2006, p. 83), for example, demonstrated bow the idea of sustainability evolved through the centuries as a counter to notions of progress' and concluded 'fears that present and future generations might not be able to maintain their living standards stimulated a mode of thinking that would inform discourses which prepared the way for the emergence and global adoption of sustainable development' (Du Pisani, 2006, p. 87). The concept re-appeared in the environmental literature in the 1970's and since then the term sustainability has become increasingly seen as offering potential solutions to a wide range of challenges and problems from the global to the local scale, across seemingly almost all walks of life. Barr (2008, p.xi), for example, claimed that 'one of the most pressing and complex question of the early twentieth-first century' is 'bow to promote the bebavioural shifts necessary for creating the sustainable society.' Diesendorf (2000, p. 21) has argued that 'sustainability' can be seen as 'the goal or endpoint of a process called sustainable development.'The most widely used definition of sustainable development is 'development that meets the needs of the present without compromising the ability of future generations to meet their own needs' (World Commission on Environment and Development, 1987, p. 43).

As investors, consumers, governments, interests groups and the media have become more acutely aware of the environmental, social and economic impacts of business activities, so corporate sustainability initiatives have assumed ever increasing importance. KPMG (2012, webpage), for example, suggested that the evidence that sustainability is becoming a core consideration for successful businesses around the world grows stronger every day.' While there is broad agreement that corporate sustainability is concerned with environmental, social and economic issues, there is little consensus in defining the term and, as with sustainability, a number of meanings can be identified. There are definitions which seem to emphasise business continuity. Dyllick and Hockerts (2002, p. 13), for example, defined corporate sustainability as 'meeting the needs of a firm's direct and indirect shareholders....... without compromising its ability to meet the needs of future stakeholders as well.' There are also definitions that look to include environmental and social goals and to formally incorporate these goals into corporate strategy. van Marrewijk and Werre (2002, p. 107), for example, argued that 'corporate sustainability refers to a company's activities - voluntary by definition - demonstrating the inclusion of social and environmental concerns.' In some ways Amini and Bienstock (2014, p.13) combined both approaches and argued that corporate sustainability 'embraces the idea that an organization, in order to remain fundamentally sustainable in the long term, must consider all of the contexts in which it is embedded: economic, social and environmental.'

More generally corporate sustainability is also increasingly seen to be linked to the more recently developed concept of the creation of shared value. This concept has been 'defined as policies and practices that enhance the competitiveness of a company, while simultaneously addressing the economic and social conditions in the communities in which it operates'(Porter and Kramer, 2011, p. 78). Essentially Porter and Kramer (2011) suggested that the purpose of the corporation had to be redefined as creating economic values in a way that also creates value for society by addressing its challenges and needs, and the concept has been adopted by a small, but growing, group of large companies. Nestle (2017, webpage), for example, claimed that looking to the future creating shared value remains a fundamental guiding principle of how we do business' and that 'ourpositive impact on society focuses on enabling healthier and happier lives for individuals and families, on helping the development of thriving and resilient communities and, finally, on stewarding the planet's natural resources for future generations'

The growing interest in, and commitment to, corporate sustainability has seen the emergence of sustainability reporting across a wide range of companies and organisations. In essence sustainability reporting is a general term used to describe how a company, or an organisation, publicly reports on its environmental, social and economic impacts and performance. For the Global Reporting Initiative (2011, webpage) 'sustainability reporting is the practice of measuring, disclosing, and being accountable to internal and external stakeholders for organizational performance towards the goal of sustainable development.' van Wensen et al. (2011, p. 14) argued that 'sustainability reporting is the provision of environmental, social and governance information within documents such as annual reports and sustainability reports.'

A number of private companies and voluntary organisations offer sustainability reporting services and frameworks but the United Nations Environment Programme (2013, p. 21), argued that the Global Reporting Initiative 'has become the leading global framework for sustainability reporting.' 'Within the current Global Reporting Initiative (G4) guidelines materiality and external assurance are seen to be of central importance. Materiality is 
concerned with who is involved in identifying the environmental, social and economic issues that matter most to a company and its stakeholders and how this process is undertaken. External assurance is a procedure employed to provide confidence in both the accuracy and the reliability of the reporting process. External providers offer two levels of assurance namely 'reasonable' (high but not absolute) and 'limited' (moderate) and the higher the level of assurance the more rigorous the assurance process. More generally the increasing focus on materiality and external assurance reflect calls for greater transparency within sustainability reporting.

\section{FRAME OF REFERENCE AND METHOD OF ENQUIRY}

In an attempt to obtain an exploratory review of how the UK waste management industry is approaching sustainability the authors selected the top ten waste management companies operating in the UK namely, Veolia Environmental Services; Biffa Group; Pennon Group; Suez Environment; FCC Environment; DS Smith Recycling; Shanks Group; DCC; SRCL and Tradebe, as identified by the Chartered institute of Waste Management (2015). As the leading players within the UK's waste management industry the selected companies might be seen to reflect contemporary approaches to sustainability within the sector and to be keen to publicise their sustainability initiatives to a wide audience. Companies have employed a range of methods to report on their sustainability commitments and achievements but publication on corporate websites has become the most popular and the most accessible reporting mechanism (Morhardt, 2009). This led the authors to conduct a digital Internet search for information, using the key phrase 'sustainability report' and the name of each of the selected waste management companies. This search was undertaken in August 2017, employing Google as the search engine, and the most recent reports for each of the selected companies obtained from this search process provided the empirical information for this paper. While some of the selected companies operate on an international scale, as noted earlier, and reported on a many of their achievements in a range of counties in their sustainability reports, the authors looked to use examples drawn from the UK for the empirical material in the paper.

The authors took the decision to tease out the key themes and narratives by a close inspection of the sustainability reports on the selected companies' corporate web sites. The specific examples and selected quotations drawn from the leading waste management companies' corporate websites cited below are used for illustrative rather than comparative purposes, with the focus being on conducting an exploratory examination of the current sustainability issues being addressed by the leading companies within the waste management industry rather than on providing a systematic analysis and comparative evaluation of sustainability policies and achievements of those companies. Unless specifically cited all quotations are drawn from the selected companies' sustainability reports. The paper is based on information that is in the public domain and the authors took the considered view that they did not need to contact the selected companies to obtain formal permission prior to conducting their research. When outlining the issues of reliability and validity in relation to information drawn from the Internet, Saunders et al. (2009) emphasised the importance of the authority and reputation of the source and the citation of a specific contact individual who can be approached for additional information. In reviewing the sustainability reports the authors felt that the two conditions were met.

\section{FINDINGS}

Four of sets of findings emerged from the review of the sustainability reports relating to the nature of the reporting process; the environmental, social and economic issues reported as part of the companies' sustainability strategies; the issues of materiality and external assurance; and a number of interlinked themes underlying the companies' commitments to sustainability. Firstly, the findings revealed marked variations in the nature and style of the corporate sustainability reporting process amongst the top ten waste management companies operating within the UK. Six of the selected companies namely, Biffa Group, FCC Environment, D S Smith Recycling, Shanks Group, SRCL and Tradebe had posted dedicated sustainability or corporate social responsibility reports, three of the companies namely, Veolia Environmental Services, Pennon Group and Suez Environmental and posted a combined annual and sustainability report, while the remaining company, DCC, included a short sustainability report within its annual reports. The reports varied considerably in length and in the depth and detail of their coverage. Each of the waste management companies operating in the UK reported on their sustainability strategies and agendas and on their achievements against those agendas in their own individual ways. There was little or no uniformity in the character, layout or length of the sustainability reports posted by the selected companies. Some of the selected companies provided detailed structured narratives and supporting data while others offered a lighter and less detailed commentary. Some of the selected companies reinforced their narratives with selected single year or time series data, often across three years, and/or graphical representations of such data. The selected companies illustrated the narrative in their sustainability reports with cameo 'case studies' and with 
short quotations from senior company executives as well as with diagrams and photographic images. Only two of the selected companies, namely Suez Environment and DS Smith claimed that its report had been prepared with reference to the Global Reporting Initiative (G4) framework. Only Suez Environmental provided detailed time series data on the standard environmental, social and economic indicators specified in this framework, as well as on more general range of environmental and social performance indicators.

Secondly the majority of the top ten waste management companies operating in the UK emphasised their corporate concern for, and commitment to, sustainability. FCC Environmental, for example, reported 'our vision is to be the environmental company of choice, delivering change for a sustainable future', while the Shanks Group stressed that 'sustainability is at the heart of everything we do.' Suez Environment reported 'our ambition is to become the leader in sustainable resource management' and in his forward to the Biffa Group's corporate social responsibility report Ian Wakelin, the company's Chief Executive, emphasised that 'our position in the waste and resources chain means that we are integral to the supply of sustainable solutions for our customers and therefore corporate social responsibility is at the heart of everything we do.' D.S. Smith emphasised 'we value sustainability as it is the cornerstone of our overall business strategy' and stressed its 'continuing commitment to conducting business in a responsible and sustainable manner' while SRCL claimed 'sustainability has always been a focus and priority for our business.'

Such strategic commitments were illustrated across a range of environmental, social and economic agendas. A number of interlinked environmental issues were addressed by the top ten waste management companies operating in the UK including waste management processes and recycling, climate change and carbon dioxide emissions, energy efficiency, water management, land restoration and the promotion of biodiversity and ecosystem services. Tradebe, for example, reported on its environmental waste performance and in focusing on chemical waste, for example, emphasised that 'in the first instance we always look, to recycle waste chemicals' and reported that recycled chemicals were either returned to the original user or repackaged for resale. The company specifically reported that in 2016 its plants in Sunderland, Knottingley, Heysham and Rye received 100, 000 tonnes of waste chemicals for processing, and that $64 \%$ was recycled to high quality chemicals, $20 \%$ was sent for processing into secondary liquid fuel and the remainder, largely non-hazardous waste water, was sent to third party effluent treatment plants. In a similar vein Shanks Group outlined its activities in converting waste products into recyclables, green energy and recovered fuel and on its employment of a range of technologies for sorting, treating and processing waste and reported that in $2016,84 \%$ of the 8.4 million tonnes of waste handled at the company's sites was recovered and recycled.

The issues of climate change and energy efficiency were addressed, albeit in different measure, in all selected companies' sustainability reports. Under the banner headline 'Ongoing Mobilization for Climate Change', Suez Environmental, for example, reported delivering 'solutions that help to fight climate change' which the company described as 'the main challenge facing mankind at the start of the 21st century' and 'on including carbon price in its investment decisions, to encourage investment in clean energy and to promote an increasingly carbon-free economic and environmental model.' Veolia outlined its focus on three priorities designed to help implement the Paris Climate Agreement namely promoting the circular economy more widely to avoid fossil fuel use, capturing and recovering methane and lobbying for the introduction of a robust and stable carbon price to enable low carbon solutions to be rolled out. On the issue of carbon pricing, for example, the company reported that it had set an internal price for carbon which was being used as one of the assessment criteria for all projects and as one element taken into consideration when choosing between different investment opportunities. DCC reported on its compliance with the nationally determined requirements of the European Union Energy Efficiency Directive Article 8 in all its business operations and that this was achieved through a range of measures including the completion of detailed energy efficiency audits at the company's larger processing facilities and of its fleet of vehicles. While DCC provided summary data that showed that its carbon intensity (as measured by carbon dioxide emissions per unit of revenue) had fallen by some 10\% between 2011 and 2016, its total carbon emissions had increased by $2.5 \%$ over the same time period. Under the headline 'driving fuel Efficiencies' FCC Environment reported on looking to reduce the volume of diesel fuel used by its fleet of vehicles by some $10 \%$ using fuel intelligence technology.

Water management is also seen as an important issue by some of the selected companies. Suez Environmental, for example, reported on joining the Business Alliance for Water and Climate Change, which looks to encourage businesses to measure and reduce their impact on water and argued that 'the resilience of water resources is also at the beart of the fight against climate change.'At a more local level Biffa Group reported undertaking a number of site surveys in an attempt to assure the efficiency of its water usage. These surveys revealed some 11,000 litres of leakage and Biffa Group reported that its remedial work on these problems would reduce the company's water usage and environmental impact. Pennon Group stressed its aim 'to ensure the safe and efficient removal and disposal of wastewater' and the company reported on continuing to implement a programme of wastewater treatment improvements and monitoring arrangements. D S Smith reported that the company used wastewater treatment systems to ensure that the effluent discharged from the company's plants was purified, ecologically safe and met all regulatory requirements. While the volume of waste being sent to landfill has declined this method of waste disposal has 
legacy implications. FCC Environment, for example, reported that during 2016 the company restored over 73 hectares of land with a range of final end uses including woodland for nature conservation, parkland for public open space and wildflower meadows. More generally as part of its 'contribution to the common good' Suez Environment listed its commitment 'to promote biodiversity and ecosystem services.'

In reviewing the social dimensions of sustainability being addressed by the selected companies a number of themes can be identified including, the importance of employees, diversity, health and safety, and community relations. Pennon Group, for example, argued 'our success comes from our talented people doing great things for our customers and each other.' Under the headline 'Our People' Shanks Group claimed 'investing in our people and their development helps us ensure that we grow our business for the future.' In focusing on 'equipping our people to manage change', Shanks Group reported 'building a culture where employees are encouraged to share best practices and use the ideas of others wherever this can accelerate business improvement.' Further, in addressing diversity the Shanks Group argued 'we benefit enormously from our diverse workforce. Our people come from different backgrounds and from a wide range of cultures, creating vibrant workforce where we can all learn from on another' and the company reported 'the importance of diversity, equality and non-discrimination is highlighted in our code of conduct' and is underpinned by our values, guiding the respectful way we behave towards one another.'

FCC Environment emphasised 'the health, safety and wellbeing of our colleagues is absolutely paramount and always will be' and 'the importance of keeping ourselves, our customers and our visitors safe while they are at work is central to our business values.' More specifically FCC Environment reported on the introduction of a new three year (2017-2020) Health and Safety Plan and the continuing roll-out of its Behavioural Safety Programme, which looks to encourage managers and employees to improve their safety performance by identifying safety breaches caused by poor behaviour. In addressing wellbeing the company reported launching a monthly wellbeing bulletin and on its participation in the National Eye Care Week and its organisation of an Employee Health Week and a Mental Health Week. Community relationships and charitable donations also featured in the selected companies' sustainability agendas. Tradebe, for example, argued that it 'plays an active and positive role in the communities in which we operate' and that 'as a significant employer we provide jobs, prosperity and local investment and ensure that we actively contribute to our local areas, as well as acting as a responsible and conscientious neighbour.' DCC reported on its support for charities and local communities, by direct financial contributions, by fundraising and by the provision of skills and training. Pennon Group reported that is employees are enthusiastic participants in company sponsored volunteering programmes embracing, for example, educational outreach, toy appeals for children in Manchester and Keep Britain Tidy's BeachCare programme.

Economic issues generally received limited explicit coverage in the sustainability reports posted by the top ten waste management companies operating within the UK but included employment creation, supplier relationships, local sourcing and creating value for stakeholders. Suez Environmental, for example, provided a cartographic illustration of its 'socio economic footprint in Europe', which included details of the total number of jobs supported by the company's activities in nine European countries. In the UK, for example, the company had some 5, 500 employees and claimed that it supported a further 4,000 jobs in its supply chain. Under the headline Economic Profitability That Benefits All' Suez Environment stressed its commitment 'to further strengthen its commitment to local development and to regions in which it operates.' Suez Environment further reported on its 'purchasing and subcontracting policy that favours the local economic fabric, particularly small and medium sized businesses, partnerships with organisations working in the field of social and responsibly economy and the increased use of sources in the adapted and protected labour sectors.'

Thirdly only two of the selected companies, namely Suez Environmental and D S Smith provided information on the materiality analysis undertaken to reveal and prioritise environmental, social and economic issues according to their potential impact on the company's activities and their importance to stakeholders. In the materiality assessment conducted by Suez Environmental, for example, 51 issues were assessed according to four sets of factors. Namely the press coverage they had received in the previous six months; their importance to a range of internal and external stakeholders; their negative or positive impact on the company's financial results over the previous five years; and the degree of command of the operational processes implemented by the company to address the issues. D S Smith argued that the results of its materiality analysis informs our approach to sustainability, enabling us to focus on the issues that are most important to our stakeholders, those which are likely to impact our business the most and those areas in which we can have the most influence.'

Two of the selected companies, namely DCC and D S Smith reported commissioning independent external assurance of some of the environmental data in their sustainability reports, but in both cases this was limited, rather than reasonable, assurance as defined earlier. The external assurance for D S Smith undertaken by Bureau Veritas, for example, covered energy consumption, raw material usage, water consumption, waste and discharge to air and water and the assurers concluded there is no evidence to suggest that the data presented here is not a fair and accurate presentation of D S Smith's performance.' The external assurance of the environmental performance data reported by DCC, undertaken by KPMG, was devoted solely to carbon emissions. Suez Environment reported commissioning external assurance of a wide range of environmental performance indicators and of a range of social and community indicators. 
Fourthly the leading waste management companies' general and specific commitments to sustainability were often informed and underpinned by a number of interlinked themes namely, technological innovation, the creation of shared value, the circular business model and a commitment to continuing growth. The majority of the top ten waste management companies operating in the UK stressed the importance of innovation and new technologies in improving efficiency across the sustainability spectrum. Suez Environmental, for example, argued that 'new solutions for resource protection or disruptive economic models often originate in start-ups or positive-impact enterprises' and reported that it was working with a number of such small companies to 'build an open innovation system', for example, to recover organic waste and to prevent exposure to micro pollutants. At the same time Suez Environmental suggested that 'digital technology allows for dematerialized procedures, the structuring of short circuits and the smart management of facilities.'Pennon Group claimed 'from the technology and science we use through to the way we approach what we do-innovation drives us forward.' At the company's new waste water treatment facility in Plymouth, for example, the combined technologies of suspended ion exchange, inline coagulation and ceramic membrane filtration will be used for the first time in the UK. In a similar vein 'driving innovation' was described as a key element in Tradebe's corporate strategy for its activities in the UK. More specifically Tradebe suggested that 'industry faces a real challenge as the production of offensive waste increases and the available disposal routes decrease' and argued that 'it is vital that Tradebe remains at the forefront in the pursuit of alternative technologies to meet this increasing demand.'

A number of the selected companies highlighted their commitment to creating value and here the focus was often on shared value. DCC for example, subtitled the short sustainability report within its annual report 'Creating Sustainable Value for Our Stakeholders' and argued that in looking to achieve this goal the company would 'enhance our reputation with stakeholders and protect the value we create over the longer term.' More specifically in addressing shared value, DCC cited the growth in the number of its employees, its graduate recruitment and development programme and its work with a social enterprise which connects businesses with surplus food to charities in the local community. Suez Environmental provided a graphic illustration of its 'shared value' which embraced human capital, environmental capital, financial capital, intellectual capital and social capital. The shared value of environmental capital, for example, was illustrated by 9.5 million tonnes of carbon dioxide emissions being avoided and $92 \%$ of the company's wastewater being depolluted, that of financial capital by the 602 million Euros distributed to shareholders and that of intellectual capital by 1.4 million hours of employee training.

A number of the selected companies reported on their commitment to the concept of the circular economy and to a circular business model. In reporting on it strategy to be 'the world leader in sustainable resource management', Suez Environmental, for example, reported that it was 'fully committed to advancing the cause of the circular economy' and suggested that the UK was 'at the forefront of the circular economy' and suggested that by transforming its activities and 'integrating them into a circular economic model' the company is 'driving optimisation of operational performance.' Biffa Group claimed that 'the journey to a more circular economy has been embraced by the waste management and resource sector', argued that the company had 'been instrumental in shaping circular economy thinking' and reported that in its long standing relationship with Wyevale Garden Centres, Biffa Group was 'changing behaviours and embedding circular economy principles into daily operations.' 'Tradebe stressed its commitment to the circular economy and argued 'we must reinforce at all levels the importance of recycling and reuse in order to optimise and maximise the value and utilisation of natural resources and raw materials in a transition into a more sustainable and circular economic model.'

With an eye to the future the sustainability reports posted by a number of the top ten waste management companies operating within the UK were couched within the idiom of continuing growth and business expansion. Veolia, for example, emphasised that its strategy 'is based on the dual dynamic of growth and efficiency' and reported that 'our focus on growth aims to amplify our organic expansion' and that 'our healthy reservoir of projects in the pipeline - along with contracts signed in 2016 but not yet fully reflected in our results - provide us with solid hope for year-on-year revenue growth.' Tradebe reported that 'generating increased organic growtb' was a key element in its corporate strategy and Shanks Group cited a number of examples of how its commitment to sustainability 'belps us to grow our business for the future.' Pennon Group reported that 'looking abead, our strong operational and financial performance shows we are delivering on our strategy and providing a firm foundation for future growth.'

\section{DISCUSSION}

A number of sets of issues merit discussion and reflection. While the top ten waste management companies operating within the UK emphasised their commitment to sustainability, the terms sustainable development and sustainability, are rarely formally or explicitly defined within their sustainability reports. That said these reports include implicit definitions of sustainability which consistently emphasise business continuity rather than the preservation and enhancement of natural and social capital. Such definitions are primarily built around business efficiency and cost savings and are driven largely by business imperatives. Thus while many of the environmental agendas addressed by the selected companies are designed to reduce carbon dioxide emissions and to increase energy efficiency, for example, they also serve to reduce operating costs. In a similar vein the selected companies' 
commitments to their employees focusing for example, upon empowering employees and health and safety, help to promote stability, security, loyalty and efficiency amongst the workforce.

Although the top ten waste management companies operating within the UK addressed a range of environmental, social and economic agendas in their sustainability reports there are issues about the selection of these agendas and about the independent assurance of the data provided to illustrate achievements against these agendas. With the two exceptions noted earlier, there was no reference as to how material issues were identified by the companies or to the role of a range of external stakeholders in the identification process. As such the sustainability reports posted by the majority of the selected waste management companies might be seen to represent the executive management's approach to sustainability rather than the potentially wider sustainability agendas and concerns of the company's stakeholders. At the same time the approach to the construction of materiality matrices employed by some of the leading companies within the waste management industry might be seen to suggest the corporate privileging of sustainability goals rather than environmental, social and economic concerns. McElroy (2011, webpage), for example, claimed that this approach 'essentially cuts out consideration of what are arguably the most material issues' namely 'the broad social, economic and environmental impacts of an organisation regardless of bow they relate to a particular business plan or strategy.' More generally this, in turn, could be seen to suggest that the selection and prioritisation of environmental, social issues and economic issues might be seen to reflect the use of sustainability reporting as a way of creating a positive reputation for the waste management companies and of gaining competitive advantage in the market place.

The lack of independent external assurance of the data in the sustainability reports posted by the majority of the top ten waste management companies operating within the UK can also be seen to be problematic. This can be seen to reduce the credibility, integrity and reliability of the sustainability reporting process undertaken by the selected companies. That said the selected companies are large, complex and dynamic organisations and capturing and storing comprehensive information and data throughout the supply chain in a variety of geographical locations and then providing access to allow external assurance is a challenging and a potentially costly venture. Thus while data on a company's carbon emissions may be systematically collected, collated and audited as part of the company's environmental commitments, information on their impact on local communities and levels of staff satisfaction may be more difficult to measure, collate, interpret and assure. Currently, the majority of the top ten waste management companies operating within the UK choose not to publicly pursue such an exercise.

The majority of the top ten waste management companies operating within the UK certainly see continuing innovation and technological development as vitally important in achieving more efficient resource use across the sustainability spectrum. More generally Clark and Dickson (2003, p. 8059) suggested that the need for sustainable development initiatives to mobilize appropriate science and technology has long been recognized' and advances in technology are often seen to provide the best way of promoting greater efficiency. However while Schor (2005, p. 310) recognised that 'advocates of technological solutions argue that more intelligent design and technological innovation can dramatically reduce or even stop the depletion of ecological resources', he argued that such approaches 'fail to address increases in the scale of production and consumption, sometimes even arguing that such increases are not unsustainable if enough natural-capital-saving technical change occurs.'

Value creation has traditionally been seen as one of the major objectives of businesses, though in posing the question 'for whom is value created' Haksever et al. (2004, p. 291) drew attention to whether companies must create value for its shareholders or more generally for all stakeholders. In addressing value creation a number of the selected companies detailed benefits to both shareholders and stakeholders and such would seem to reflect the concept of shared value. That said Crane et al. (2014) identified a number of weaknesses and shortcomings in the creation of shared value model. More specifically Crane et al. (2014, p. 131) argued that the model 'ignores the tensions between social and economic goals', that it is 'naïve about the challenges of business compliance' and that it is 'based on a shallow conception of the corporation's role in society.' In examining the first of these concerns, for example, Crane et al. (2014, p. 136) suggested that 'many corporate decisions related to social and environmental problems, bowever creative the decision-maker may be, do not present themselves as potential win-wins, but rather manifest themselves in terms of dilemmas.' As such Crane et al. (2014, p. 136) suggested that such dilemmas are effectively 'continuous struggles between corporations and their stakeholders over limited resources and recognition.'

In theory the ideas underpinning the concept of the circular economy might seem straightforward, but in practice a number of operational challenges can be identified. Ritzen and Sandstrom (2017), for example, identified a number of attitudinal, financial, structural, and technological barriers to a transition to a more circular economy. A shift towards a circular model was also perceived to require far reaching changes within companies and such changes take both time and investment and where corporate financial systems are focused on rapid returns on investment and cost savings this currently does not encourage long term strategic change. There are also challenges in developing indicators or measures that might help to monitor how a product or a company is progressing towards the circular economy and at the same time corporate finance departments are still developing and refining tools to measure the financial costs and benefits of pursuing circular business models. It is also important to recognise that the transition to a circular economy will both drive and demand major changes in consumer 
behaviour and consumption patterns. Such a transition may, for example, require dramatic changes in way in which consumers approach consumption and it seems likely to challenge the social value which consumers ascribe to many products and services.

While the circular economy has a strong environmental focus much less attention has been paid to the social dimension. Murray et al. (2015, p. 22), for example, argued that the circular economy is virtually silent on the social dimension, concentrating on the redesign of manufacturing and service systems to benefit the biosphere.' A number of issues may be important here. While the transition to a circular economy will bring socio-economic benefits, for example in terms of the creation of new employment opportunities associated with the establishment of new waste management and recycling facilities, issues may arise in terms of the quality of such opportunities, the reward levels associated with them and the geographical distribution of such benefits at regional, national and international levels. More generally the impact of an increasingly important circular economy on social and intergenerational equity, seen to be fundamental to sustainable development, and to the United Nation's Sustainable Development Goals launched in 2015, may prove a complex and testing set of issues.

The sustainability reports posted by a number of the top ten waste management companies operating within the UK are couched within the idiom of continuing growth and there are debates about whether continuing economic growth is compatible with sustainability. On the one hand the dominant corporate argument is that continuing economic growth will inevitably be accompanied by the more efficient use of resources. This trend which is seen as either relative or absolute decoupling (relative decoupling refers to using fewer resources per unit of economic growth while absolute decoupling refers to a total reduction in the use of resources) underpins many conventional definitions of sustainability and the vast majority of current corporate sustainability strategies and programmes. Veolia, for example, recognised that 'natural resources are becoming increasingly scarce while the planet's needs are growing' but argued that the company 'designs and implements solutions aimed at improving access to resources while at the same time protecting and renewing those same resources.' More explicitly Suez Environmental argued that 'the desire to separate growth from the consumption of natural resources is growing' and that 'green and inclusive growth is possible.'

On the other hand some critics have suggested that continuing economic growth, dependent as it is, on the seemingly ever increasing depletion of the earth's natural resources is fundamentally incompatible with sustainability. Daly (2017, p. 85), for example, suggested that 'there is an obvious physical conflict between the growth of the economy and the preservation of the physical environment' while Higgins (2013, webpage) argued 'the economic growth we know today is diametrically opposed to the sustainability of our planet.' Decoupling is seen by some critics as an elusive goal and Conrad and Cassar (2014, p. 6370) suggested that 'a substantial body of research has cast doubts on whether countries can truly grow their way out of environmental problems. Arguably more radically Jackson (2009, p. 57) concluded a discussion of what he described as 'the myth of decoupling' by arguing that 'it is entirely fanciful to suppose that deep emission and resource cuts can be achieved without confronting the structure of market economies.' In a similar radical vein, Valenzuela and Bohm (2017, p. 23) argued that while 'the concept of sustainability was originally brought to light to stand against the growth doctrine of capitalism and the overconsumption of natural resources', four decades later 'the term sustainability has been captured by politiceconomic elites claiming that rapid economic growth can be achieved in a way that manages to remain responsible to environment and society.' Equally critically Castro (2004) has questioned the very possibility of sustainable development under capitalism and argued that economic growth relies upon the continuing and inevitable exploitation of both natural and social capital.

\section{CONCLUSIONS}

All the top ten waste management companies operating within the UK publicly reported on their commitments to sustainability and on their achievements in meeting such commitments. A number argued that by integrating sustainability into their businesses, they are creating sustainable value, are better placed to provide long term growth and financial security for all stakeholders and to enhance their market position and reputation. However, the authors argue that the selected companies definitions of, and commitments to, sustainability can be interpreted as being driven as much by business imperatives as by any fundamental commitments to sustainability. Thus the accent currently appears to be on making efficiency gains across a wide range of economic, social and environmental issues rather than on maintaining the viability and integrity of natural ecosystems and on reducing demands on finite natural resources. As such the top ten waste management companies operating within the UK are, at best, pursuing a 'weak' rather than a 'strong' model of sustainability. More critically the authors suggest that the selected companies' commitments to sustainability are couched within existing business models centred on continuing growth and consumption and that current policies might be viewed as little more than genuflections to sustainability. This echoes Roper's (2012) belief that weak sustainability represents 'a compromise that essentially requires very little change from dominant economic driven practices but effectively works to defuse opposition, increase legitimacy and allow business as usual.' As such the sustainability reports published by the leading players within the waste management industry within the UK might be seen to be part of wider marketing and public relations strategies designed to 
assuage government, consumers' and pressure group concerns about the environmental and social impacts of their activities, to enhance the industry's reputation with shareholders and policy makers and to further its commercial interests and agendas.

At the same time, the nature of the reporting process adopted by the majority of the leading waste management companies operating within the UK might be seen to leave something to be desired, not least in the seeming reluctance to comply with global Reporting Initiative guidelines, to address the issue of materiality, to commission independent external assurance and to provide a range of environmental, social and economic performance indicators. Certainly the authors would argue that the sustainability reports published by some of the leading operators within the UK waste management industry compare less favourably with those produced elsewhere in the service industries (Jones et al., 2011; Jones et al., 2014). Looking to the future and in the face of growing media, investor, customer, pressure groups and government scrutiny, the top ten waste management companies operating in the UK may seek to further develop, and adopt, a more rigorous and transparent approach to their sustainability reporting. Here the leading players in the waste management industry within the UK may want to address how they can continue to reflect on corporate approaches to sustainability, on the development of such approaches over time and on how to bring greater value and transparency to the reporting process. At the same time future academic research agendas might usefully build on the current paper by focusing on a number of avenues of enquiry. These might include, for example, detailed investigations of the ways the major players within the waste management industry are engaging with stakeholders to identify material issues, into how the waste management industry looks to manage sustainability issues throughout its supply chain and into whether greater transparency in the sustainability reporting process is reflected in corporate investment and profitability.

\section{REFERENCES}

Amini, M. and Bienstock, C. C. (2014). Corporate sustainability: an integrative definition and framework to evaluate corporate practice and guide academic research. Journal of Cleaner Production, 76(1), 12-1. https://doi.org/10.1016/j.jclepro.2014.02.016

Apex Insight. (2013). UK Waste Management: Market Insight. [online] Available at: https://www.apexinsight.com/product/uk-waste-management-market-insight/ (Accessed 21 August 2017)

Aras, G. and Crowther, D. (2008). Governance and Sustainability: An investigation into the relationship between corporate governance and corporate sustainability. Management Decision, 46(3), 433-448. https://doi.org/10.1108/00251740810863870

Associate Parliamentary Sustainable Resource Group. (2012). Sustainable Skills: The Future of the Waste Management Industry, [online] Available

http://www.policyconnect.org.uk/apsrg/sites/site_apsrg/files/report/331/fieldreportdownload/apsrgsustainableskillsreport.pdf (Accessed 14 August 2017)

Barr, S. (2008). Environment and Society: Sustainability, Policy and the Citizen, Aldershot, Ashgate.

Castro, C. (2004). Sustainable Development: Mainstream and Critical Perspectives. Organisation and Environment, 17(2), 195-225. https://doi.org/10.1177/1086026604264910

Chartered Institute of Wastes Management. (2015). Big Business, [online] Available at: http:/ / www.catalystcf.co.uk/research-documents/2015/catalyst-ciwm-top-20-2015.pdf (Accessed 3 August 2017)

Clark, W. C. and Dickson, N. M. (2003). Sustainability Science: The emerging research program. Proceedings of the National Academy of Sciences of the United States of America, 100(14), 8059-8061. https:// doi.org/10.1073/pnas.1231333100

Conrad, E. and Cassar, L. F. (2014) Decoupling Economic Growth and Environmental Degradation: Reviewing Progress to Date in the Small Island State of Malta, [online] Available at: http: / $/$ www.google.co.uk/ url?sa $=$ t\&rct=j\&q=\&esrc $=$ s\&source=web\&cd=1\&ved=0ahUKEwjTxKPLhfSAhVmC8AKHZ3wBj0QFggdMAA\&url=http $\% 3 \mathrm{~A} \% 2 \mathrm{~F} \% 2 \mathrm{Fwww} \cdot \mathrm{mdpi.com} \% 2 \mathrm{~F} 2071$ -

1050\%2F6\%2F10\%2F6729\%2Fpdf\&usg=AFQjCNF67MZea95-

QhExpZEDth0N36k_Ug\&sig2=TdFAxlE2klAORjsAbVFo9Q\&bvm=bv.150120842,d.bGg (Accessed 13 March 2017)

Crane, A., Palazzo, G., Spence, L. J. and Matten, D. (2014). Contesting the Value of Creating Shared Value. California Management Review, 56(2), 130-154. https://doi.org/10.1525/cmr.2014.56.2.130

Daly, H. (2017). A New Economics for Our Full World, in P. A. Victor and V. Dolter (Eds). Handbook on Growth and Sustainability (pp. 85- 106). Edward Elgar, Cheltenham. https://doi.org/10.4337/9781783473564.00012

Department for Environment, Food and Rural Affairs. (2013). Waste Management Plan for England, [online] Available 
https://www.gov.uk/government/uploads/system/uploads/attachment_data/file/265810/pb14100-wastemanagement-plan-20131213.pdf (Accessed 6 August 2013)

Department for Environment, Food and Rural Affairs. (2017). Digest of Waste and Resource Statistics, [online] Available

https://www.gov.uk/government/uploads/system/uploads/attachment_data/file/607416/Digest_of_Waste _and_Resource_Statistics_2017_rev.pdf (Accessed 23 August 2017)

Diesendorf, M. (2000). Sustainability and Sustainable Development, in D. Dunphy, J. Beneveniste, A. Griffiths and P. Sutton (Eds). Sustainability: The corporate challenge of the 21st century (pp. 19-37). Sydney, Allen and Unwin.

Du Pisani, J. A. (2006). Sustainable Development - Historical Roots of the Concept, Environmental Sciences, 3(2), 83-96. https://doi.org/10.1080/15693430600688831

Dyllick, T. and Hockerts, K. (2002). Beyond the Business Case for Corporate Sustainability. Business Strategy and the Environment, 11(2), 130-141. https://doi.org/10.1002/bse.323

Environmental Services Association. (2017). Planning for a Circular Economy. [online] Available at: http:/ /www.esauk.org/esa_reports/20170411_Planning_for_a_Circular_Economy_FINAL.pdf (Accessed 3 August 2017)

Global Reporting Initiative. (2011). Sustainability Reporting Guidelines. [online] Available at: https://www.globalreporting.org/resourcelibrary/G3.1-Guidelines-Incl-Technical-Protocol.pdf (Accessed 12 April 2016)

Gov. UK. (2014). Waste Management in the UK: Investment Opportunities. [online] Available at: https:/ / www.gov.uk/government/publications/waste-management-in-the-uk-investment-

opportunities/waste-management-in-the-uk-investment-opportunities (Accessed 22 August 2017)

Gov. UK. (2016). ENV 23 UK Statistics on Waste. [online] Available at: https://www.gov.uk/government/statistical-data-sets/env23-uk-waste-data-and-management (Accessed 22 August 2017)

Haksever, C., Chaganti, R. and Cook, R. G. (2004). A Model of Value Creation; Strategic View. Journal of Business Ethics, 49(3), 291-305. https:/ / doi.org/10.1023/B:BUSI.0000017968.21563.05

Hamilton, C. (2009). Consumerism, self-creation and prospects for a new ecological consciousness. Journal of Cleaner Production, 18(6), 571-575. https:// doi.org/10.1016/j.jclepro.2009.09.013

Higgins, K. L. (2013). Economic growth and sustainability- are they mutually exclusive. [online] Available at: https:/ /www.elsevier.com/connect/economic-growth-and-sustainability-are-they-mutually-exclusive (Accessed 24 May 2016)

Hudson, R. (2005). Towards sustainable economic practices, flows and spaces: or is the necessary impossible and the impossible necessary? Sustainable Development, 13(4), 239-252. https://doi.org/10.1002/sd.282

Jackson, T. (2009). Prosperity Without Growth? [online] Available at: http://www.sdcommission.org.uk/data/files/publications/prosperity_without_growth_report.pdf (Accessed 4 December 2009).

Jones, P., Comfort, D. and Hillier, D. (2011). Sustainability in the Global Shop Window. International Journal of Retail and Distribution Management, 39(4), 256-271. https://doi.org/10.1108/09590551111117536

Jones, P., Hillier, D. and Comfort, D. (2014). Sustainability in the Global Hotel Industry. International Journal of Contemporary Hospitality Management, 26(1), 5-17. https:/ / doi.org/10.1108/IJCHM-10-2012-0180

Jones, P. Hillier, D. and Comfort, D. (2016). Sustainability in the Hospitality Industry; Some Personal Reflections on Corporate Challenges and Research Agendas. International Journal of Contemporary Hospitality Management, 28(1), 36-67. https://doi.org/10.1108/IJCHM-11-2014-0572

Kahn, R. (2010). Producing Crisis: Green Consumerism as an Ecopedagogical Issue, in J. A. Sandlin and P. McLaren (Eds.). Critical Pedagogies of Consumption. New York, Routledge.

KPMG. (2012). Corporate Sustainability: A Progress Report. [online] Available at: http://www.sustainabilityexchange.ac.uk/files/corporate-sustainability-a-progress-report_1.pdf (Accessed 7 May 2017)

McElroy, M. (2011). Are Materiality Matrices Really Material? [online] Available at: http://www.sustainablebrands.com/news_and_views/articles/are-materiality-matrices-really-material (Accessed 8 January2015)

Morhardt, J. E. (2009). Corporate Social Responsibility and Sustainability Reporting on the Internet. Business Strategy and the Environment, 19(7), 436-452. https://doi.org/10.1002/bse.657

Murray, A., Skene, K. and Haynes, K. (2015). The Circular Economy: An Interdisciplinary Explanation of the Concept in a Global Context. [online] Available at: http://eprint.ncl.ac.uk/file_store/production/208884/EB16068A-8D6E4D8F-9FA3-83DF5775D4FE.pdf (Accessed 26 July 2017)

Nestle. (2017). Building on Creating Shared Value. [online] Available at: http://www.nestle.com/csv/what-is-csv (Accessed 28 May 2017) 
Ortiz-Rodriguez, O., Castells, F. and Sonnemann, G. (2009). Sustainability in the construction industry: a review of recent developments based on LCA. Construction and Building Materials, 23(1), $28-39$. https://doi.org/10.1016/j.conbuildmat.2007.11.012

Porter, M. E. and Kramer, M. R. (2011). Strategy and Society: The link between competitive advantage and corporate social responsibility. Harvard Business Review, 87, 78-92.

Ritzen, S. and Sandstrom, G. O. (2017). Barriers to a Circular Economy - Integration of Perspectives and Domains. Procedia CIRP, 64, 7-12. https://doi.org/10.1016/j.procir.2017.03.005

Roper, J. (2012). Environmental risk, sustainability discourses and public relations. Public Relations Inquiry, 1(1), 6987. https://doi.org/10.1177/2046147X11422147

Saunders, M., Lewis, P. and Thornhill, A. (2009). Research Methods for Business Students. Harlow, Prentice-Hall.

Schor, J. B. (2005). Prices and Quantities: Unsustainable Consumption and the Global Economy. Ecological Economics, 55(3), 309-320.

United Nations Environment Programme. (2013). Frequently Asked Questions on Corporate Sustainability Reporting. [online] Available at: https://www.globalreporting.org/resourcelibrary/GoF47Para47-FAQs.pdf (Accessed 6 April 2016)

Valenzuela, F. and Bohm, S. (2017). Against Wasted Politics: A Critique of the Circular Economy. Ephemera: Theory and Politics in Organization, 17(1), 23-60.

van Wensen, K., Broer, W., Klein, J. and Knofp., J. (2011). The State of Play in Sustainability Reporting in the European Union. [online] Available at: http://ec.europa.eu/social/main.jsp?langId=en\&catId=89\&newsId=1013 (Accessed 4 April 2016)

van Marrewick, M. and Werre, M. (2002). Multiple Levels of Corporate Sustainability. [online] Available at: http:/ / vanmarrewijk.nl/pdf/021206131353.pdf_(Accessed 18 March 2016)

Weise, A., Kellner, J., Lietke, B., Toporowski, W. and Zielke, S. (2012). Sustainability in retailing - a summative content analysis, International Journal of Retail \& Distribution Management, 40(4), $318-335$. https://doi.org/10.1108/09590551211211792

World Commission on Environment and Development. (1987). Our Common Future. [online] Available at: http:/ / www.un-documents.net/ocf-02.htm (Accessed 30 July 2014). 